\title{
Vermicompost and gypsum amendments improve aggregate formation in bauxite residue
}

by Zhu, F., Jingao, H., Xue, S., Chuan, W. Qiongli, W. and Hartley, W.

Copyright, Publisher and Additional Information: This is the author accepted manuscript. The final published version (version of record) is available online via Wiley Please refer to any applicable terms of use of the publisher.

DOI: http://dx.doi.org/10.1002/ldr.2737

Harper Adams

University

Zhu, F., Jingao, H., Xue, S., Chuan, W. Qiongli, W. and Hartley, W. 2017. Vermicompost and gypsum amendments improve aggregate formation in bauxite residue. Land Degradation and Development. 


\title{
VERMICOMPOST AND GYPSUM AMENDMENTS IMPROVE
}

\section{AGGREGATE FORMATION IN BAUXITE RESIDUE}

\author{
Feng Zhu ${ }^{1,2}$, Guo Ying ${ }^{1}$, Shengguo Xue ${ }^{1, *}$, Wu Chuan ${ }^{1}$, William Hartley ${ }^{3}$ \\ ${ }^{1}$ School of Metallurgy and Environment, Central South University, Changsha 410083, PR China \\ ${ }^{2}$ South China Institute of Environmental Sciences, Ministry of Environmental Protection, Guangzhou 510655, PR China \\ ${ }^{3}$ Crop and Environment Sciences Department, Harper Adams University, Newport, Shropshire, TF10 8NB, United Kingdom
}

\begin{abstract}
Improving aggregate formation and stability of bauxite residue is essential for the development of a soil on the residue. Effects of gypsum and vermicompost on related chemical and physical conditions of bauxite residue were studied in a laboratory incubation experiment. Addition of gypsum at $2 \%$ and $4 \% \mathrm{w} / \mathrm{w}$ reduced $\mathrm{pH}$ and exchangeable sodium percentage, whilst increasing exchangeable calcium content. Addition of vermicompost reduced bulk density, whilst significantly increasing porosity and total organic carbon. Vermicompost had a positive effect on the formation and stabilization of water-stable aggregates in the residue, whilst gypsum was more beneficial to silt-sized microaggregate flocculation. Amendments also enhanced the erosion resistance of bauxite residue. Furthermore, wet sieving using the modified Le Bissonnais' (LB) method revealed that in comparison to differential clay swelling and mechanical breakdown, slaking was the major disaggregation mechanism of residue aggregates. The combination of gypsum and vermicompost converted the residue from a sheet-like structure to a granular macroaggregated structure, whilst converting microaggregates from a grain to a granular or prismatic structure. The findings of this work suggest that application of gypsum and vermicompost to bauxite residue may directly influence aggregate size distribution and its micromorphology, resulting in the improvement of both aggregate stability and structure.
\end{abstract}

KEYWORDS: Bauxite residue; gypsum; vermicompost; aggregate formation; aggregate stability

\footnotetext{
* Corresponding author.

E-mail address: sgxue70@hotmail.com; sgxue@csu.edu.cn (Shengguo Xue)
} 
Management and disposal of mine tailings and mineral processing residues are critical issues worldwide (Smart et al., 2016). Bauxite residue is produced in alumina refineries by the Bayer process in which Al-containing minerals (e.g. bauxite) are dissolved in hot $\mathrm{NaOH}$ (Kong et al., 2017a). Globally, the inventory for bauxite residue has reached an estimated 4 billion tons, and this is rapidly growing, as approximately 120 million tons are currently produced per year (Pan et al., 2015; Xue et al., 2016). Considering its environmental risks including soda, alkalinity, heavy metals and low levels of naturally occurring radioactive materials, reuse of the residue is less than 10\% (Klauber et al., 2011; Liu et al., 2014). As a result, bauxite residue continues to be stored in impoundments (Courtney et al., 2014), which may potentially lead to water, land and air pollution (Liu et al., 2009). Similar to ecological restoration on mine tailings (Chauhan \& Ganguly, 2011), revegetation has been regarded as a promising way forward to remediate the residues on a large scale and reduce potential environmental risks (Gräfe \& Klauber, 2011; Zhu et al., 2016a).

Seeding or planting seedlings directly into newly stacked residues generally fails due to its high pH, salinity and exchangeable sodium concentrations (Wehr et al., 2006; Goloran et al., 2016). Gypsum, compost, biosolids, soil materials (e.g. subsoil, sewage sludge), and combinations of these amendments, have proved effective additions when attempting to establish a plant cover (Jones \& Haynes, 2011). Courtney \& Kirwan (2012) demonstrated that gypsum was a source of calcium and could precipitate solution alkalinity and suppress the solubility of solid phase alkalinity. Jones et al. (2012) noted that addition of compost to residue sand may improve its chemical properties as a growth medium. Kaur et al. (2016) found that the application of nitrogen fertilizer may improve bauxite residue characteristics for kikuyu grass growth, and the leaching of excess salts and alkalinity from the residues enhanced $\mathrm{N}$ uptake by the grass.

The processes of soil genesis and formation should be critically considered in order to reconstruct an ecosystem rather than just vegetation establishment (Biederman et al., 2008; Santini et al., 2015; Courtney et al., 2009; Courtney et al., 2013). Environments such as mine wastes are usually physically degraded with high bulk density, low organic carbon content, poor aggregate structure and low erosion resistance, and these parameters are useful for evaluating soil physical quality in order to assess the process of restoration (Asensio et al., 2013). Zhu et al. (2016b), for example, found that an increase in organic carbon and calcium could stimulate macroaggregate stability of bauxite residue under natural weathering processes. However, to date, little research has focused on quantification and interpretation of aggregate formation and aggregate stability of bauxite residue following the addition of amendments.

Vermicomposts have been suggested as excellent amendments to remediate soils and to improve organic carbon content and fertility, whilst alleviating salinity and improving crop growth (Falsone et al., 2016; Oliveira et al., 2015; Saha \& Kukal, 2015). Vermicomposting is a bio-oxidative process that has been reported as an effective technique for the efficient management of organic solid wastes (Fornes et al., 2012; Aksakal et al., 2016). Vermicomposts are stabilized organic materials produced by interactions between earthworms and microorganisms; they are peat-like materials, with high concentrations of humic substances, plant available macronutrients and micronutrients, high porosity and microbial activity (Verdenelli et al., 2012). Sinha et al., (2010) found that compared to compost, the quality of vermicompost was superior as it contained a large amount of finer particles and was therefore more accessible to microbes. However, scientific documentation about the effects of 
vermicompost application on residue aggregate formation is relatively scarce. Gypsum, another amendment often used to aid plant establishment, reduces $\mathrm{pH}$ and provides $\mathrm{Ca}$ (Courtney and Kirwan, 2012). The current study investigated the effect of gypsum and vermicompost on aggregate formation in bauxite residue. The objectives were: 1) to investigate the changes of related physicochemical properties of bauxite residue following addition of gypsum and vermicompost, 2) to investigate the effects of amendments on aggregate size distribution of the residues and 3) to evaluate the effects of gypsum and vermicompost on aggregate stability and aggregate morphology of the residues.

\section{MATERIALS AND METHODS}

\section{Materials}

Freshly deposited bauxite residue was collected from a disposal area in Central China $\left(35^{\circ} 24^{\prime} \mathrm{N}\right.$, $113^{\circ} 25^{\prime} \mathrm{E}$ ) during August 2015. The climate is temperate continental monsoon, with a mean annual daily temperature of $12.8^{\circ} \mathrm{C}-14.8^{\circ} \mathrm{C}$. Average annual rainfall ranges from $600 \mathrm{~mm}$ to $1200 \mathrm{~mm}$. The residues were sampled to a depth of $20 \mathrm{~cm}$, stored in polyethylene bags, returned to the laboratory, air dried for 2 weeks, sieved to $<2 \mathrm{~mm}$ and homogenized prior to amendment.

Gypsum was obtained from a plant in Hubei Province and the particles ranged from 0.02-0.25 mm. Gypsum contained 80\% (w/w) calcium sulfate. $\mathrm{pH}$ was approximately 2.86 and EC (electrical conductivity) was approximately $3.92 \mathrm{mS} / \mathrm{cm}$.

Vermicompost was collected from a farm in Jiangsu Province. The compost was produced by the decomposition of cow dung through earthworm activity. The compost had a $\mathrm{pH}$ of $6.5,30.7 \%$ organic carbon, $1.8 \%$ nitrogen, $1.5 \%$ phosphorus and $0.2 \%$ potassium.

\section{Experimental design}

Bauxite residue was amended with three concentrations of gypsum $(0,2 \%$ and $4 \% \mathrm{w} / \mathrm{w})$ which were designated as B, BG1 and BG2, respectively, and/or three concentrations of vermicompost $(0,4 \%$ and $8 \% \mathrm{w} / \mathrm{w}$ ) which were designated as $\mathrm{B}, \mathrm{BF} 1$ and $\mathrm{BF} 2$, respectively. Each treatment was carried out in quintuplicate. Gypsum $(0,20 \mathrm{~g}$, or $40 \mathrm{~g})$ and/or vermicompost $(0,40 \mathrm{~g}$, or $80 \mathrm{~g})$ were thoroughly mixed with bauxite residue $(1 \mathrm{~kg})$ and the combinations were placed in $2 \mathrm{~L}$ plastic containers and rewetted to $70 \%$ water holding capacity. In order to displace and remove the accumulated soluble salts present in solution, several bore holes with a diameter of $0.5 \mathrm{~mm}$ were drilled in the bottom of the containers and covered with 300-mesh nylon net. The containers were then opened and placed in a greenhouse $\left(25-30^{\circ} \mathrm{C}\right)$ for 16 weeks. At the end of the incubation period, residue samples were split into two subsamples. One was stored for physical analysis, whilst the other was air-dried for 2 weeks and subsequently sieved prior to chemical analysis.

\section{Physical and chemical analyses}

Particle size distribution of bauxite residue was determined with a Malvern Mastersizer 2000 (Malvern Instruments Ltd., UK) (Santini \& Fey, 2013). pH and EC of residue samples were determined in water (ratio of solid:water 1:5) (Banning et al., 2014). Bulk density and particle density were determined by the cutting ring method and pycnometer method, respectively. Total porosity of residue samples was calculated using the following equation (Danielson \& Sutherland, 1986): 
Total porosity $(\%)=\frac{\text { Particle density }- \text { Bulk density }}{\text { Particle density }} \times 100$

Exchangeable bases were determined by extraction with $1 \mathrm{M}$ ammonium acetate $(\mathrm{pH}=7)$ and exchangeable sodium percentage (ESP) was calculated using the following equation (Zhu et al. 2016c):

$$
\operatorname{ESP}(\%)=\frac{\text { Exchangeable } \mathrm{Na}^{+}}{\sum \text { Exchangeable }\left(\mathrm{Ca}^{2+}+\mathrm{Mg}^{2+}+\mathrm{K}^{+}+\mathrm{Na}^{+}\right)} \times 100
$$

Organic carbon was oxidized by potassium dichromate and total organic carbon (TOC) was determined by ultraviolet spectrophotometry (Yilmaz, 2014). Chemical phases of the materials were characterized by X-ray powder diffraction (XRD). Residue samples were oven-dried at $60{ }^{\circ} \mathrm{C}$ and passed through a 300-mesh sieve prior to X-ray powder diffraction analysis conducted on a Bruker D8 discover 2500. X-ray diffraction patterns were collected from $10^{\circ}$ to $80^{\circ}$ at a step size of $0.04^{\circ} 2 \theta$ with a scan rate of $1^{\circ} 2 \theta / \mathrm{min}$. The PANalytical analysis package was used to identify and quantify phases of the residues (Kong et al., 2017b).

\section{Aggregate stability analysis}

As previous research assessed aggregate stability of unamended residues using the modified Le Bissonnais' (LB) method, this was selected here to test aggregate stability of amended residue samples (Zhu et al., 2016d). This method combined three disruptive tests: fast wetting (FW), slow wetting (SW) and wet stirring (WS) (An et al., 2013).

For the FW test which was sensitive to the slaking process, $1-2 \mathrm{~mm}$ residue aggregates $(6 \mathrm{~g})$ were quickly immersed in deionized water for $10 \mathrm{~min}$. For the $\mathrm{SW}$ test, which determined aggregate sensitivity for differential clay swelling, 1-2 mm residue aggregates $(6 \mathrm{~g})$ were placed on filter paper resting upon a sponge soaked in ethanol for $30 \mathrm{~min}$. For the WS test, which is sensitive to mechanism breakdown processes, $1-2 \mathrm{~mm}(6 \mathrm{~g})$ of residue aggregates were gently immersed in ethanol prior to being transferring to a conical flask of deionized water and shaken. Aggregate size distribution of the samples was determined by sieving $(1 \mathrm{~mm}, 0.25 \mathrm{~mm}$ and $0.05 \mathrm{~mm})$ in ethanol. The aggregates obtained from each sieve were collected and dried at $40^{\circ} \mathrm{C}$ for $48 \mathrm{~h}$ (Deviren Saygin et al., 2012).

Mean weight diameter (MWD), geometric mean diameter (GMD) and the erodibility factor (K) were selected as the parameters to evaluate aggregate stability and erosion resistance of the treated residues. The three parameters were calculated using the following equations (Le Bissonnais, 1996):

$$
\begin{aligned}
& M W D=\sum_{i=1}^{n} \overline{X_{i}} \times W_{i} \\
& G M D=\exp \left(\sum_{i}^{n} W_{i} \ln X_{i} / \sum_{i}^{n} W_{i}\right) \\
& K=7.954 \times\left\{0.0017+0.0494 \times \exp \left[-0.5 \times\left(\frac{\lg G M D+1.675}{0.6986}\right)^{2}\right]\right\}
\end{aligned}
$$

Where $\overline{X_{i}}$ was the mean diameter over the adjacent sieves $(\mathrm{mm}), W_{\mathrm{i}}$ was the percentage of residue aggregates in the size range and $n$ was the number of sample sieves. 
Residue samples were placed in the sieves $(0.25 \mathrm{~mm}$ and $0.05 \mathrm{~mm})$ and oscillated in distilled water and sodium hexametaphosphate solution $(25 \mathrm{~g} / \mathrm{L})$ for $5 \mathrm{~min}$. The $0.25-0.05 \mathrm{~mm}$ fraction was collected and dried at $40^{\circ} \mathrm{C}$ for $48 \mathrm{~h}$ prior to weighing. Microaggregate size distribution of $<0.05 \mathrm{~mm}$ fraction was determined using a Malvern Mastersizer 2000 (Sochan et al., 2012). Mean weight diameter $\left(\mathrm{MWD}_{\mathrm{m}}\right)$ and aggregated silt and clay (ASC) were used to assess microaggregate stability. The two indicators were positively correlated to microaggregate stability of residue samples (Mbagwu \& Auerswald, 1999). MWD $\mathrm{m}_{\mathrm{m}}$ was calculated using equation (3) and aggregated silt and clay (ASC) was calculated using the following equation:

$$
\operatorname{ASC}(\%)=(\% \text { Clay }+\% \text { Silt })(\text { calg on dispersed })-(\% \text { Clay }+\% \text { Silt })(\text { water dispersed })
$$

It is noteworthy that the greater the value of MWDm or ASC, the greater the microaggregate stability of bauxite residues (Monreal et al., 1995).

Morphological analysis

Micro-morphological analysis of macroaggregates $(2-1 \mathrm{~mm})$ and microaggregates $(<0.05 \mathrm{~mm})$ of residue samples in nine different treatments was determined using a scanning electron microscope, equipped with energy dispersive X-ray spectroscopy (ESEM, Quanta-200) (Newson et al., 2006).

Statistical analysis

All analyses were performed in quintuplicate. All data was analyzed in Excel 2003 and SPSS 19.0. Residues with different treatments were individually determined using one-way ANOVA (analysis of variance) to ensure homogeneity of variance $(P<0.05)$. Least significant difference (LSD) was used as a post hoc test for homogeneity, and Dunnett's T3 test was used in case of no homogeneity. All figures were constructed using Origin 8.0.

\section{RESULTS AND DISCUSSION}

\section{Residue properties}

As listed in Table 1, the dominant fractions of unamended bauxite residue were sand and silt, which accounted for $48.1 \%$ and $51.7 \%$, respectively. Unmanded bauxite residue (B) had a high pH (10.98) and EC $(0.98 \mathrm{mS} / \mathrm{cm})$. Most mineral soils have particle densities of $2.6-2.75 \mathrm{~g} / \mathrm{cm}^{3}$ and bulk densities of 1.3-1.6 g/ $\mathrm{cm}^{3}$ (Manrique \& Jones, 1991). Li (1998) discovered that particle density of bauxite residue ranged from 2.7 to $4.2 \mathrm{~g} / \mathrm{cm}^{3}$ due to high iron oxide content. Unamended bauxite residue had a high bulk density $\left(1.92 \mathrm{~g} / \mathrm{cm}^{3}\right)$ and poor porosity $(43.75 \%)$ (Table 1$)$. Among the exchangeable bases in the residues, exchangeable $\mathrm{Ca}^{2+}$ and $\mathrm{Na}^{+}$were the dominant bases, which accounted for $45.12 \%$ and $39.19 \%$, respectively.

With addition of gypsum, there was a pronounced decrease in the fraction of sand-sized particles whilst $\mathrm{pH}$ reduced significantly from 10.54 to 8.75 in BG1. Gypsum was confirmed to be an effective amelioratant for buffering pH in bauxite residue (Courtney \& Kirwan, 2012). Addition of gypsum may provide excess divalent cations to ensure the solubility of the formed TCA-type compounds (e.g. Eq. 7) and suppress pH (Courtney \& Kirwan, 2012). Addition of 4\% gypsum (BG2) may further reduce $\mathrm{pH}$, although the extent was small (8.75 to 8.42). 
As gypsum had a significant effect on bauxite residue mineral chemistry, three residue samples (B, BG1 and BG1F2) were selected to investigate the chemical phases of the residues. XRD analysis of unamended residue revealed the presence of crystalline phases of chemical minerals (Fig. 1). The alkaline minerals in bauxite residue include andradite $\left(\mathrm{Ca}_{3}\left(\mathrm{Fe}_{0.87} \mathrm{Al}_{0.13}\right)_{2}\left(\mathrm{SiO}_{4}\right)_{1.65}(\mathrm{OH})_{5.4}\right)$, cancrinite $\left(\mathrm{Na}_{8} \mathrm{Al}_{6} \mathrm{Si}_{6} \mathrm{O}_{24}\left(\mathrm{CO}_{3}\right)\left(\mathrm{H}_{2} \mathrm{O}\right)_{2}\right)$, calcite $\left(\mathrm{CaCO}_{3}\right), \quad$ grossular $\left(\mathrm{Ca}_{3} \mathrm{Al}_{2} \mathrm{Si}_{3} \mathrm{O}_{12}\right), \quad$ and katoite $\left(\mathrm{Ca}_{3} \mathrm{Al}_{2}\left(\mathrm{SiO}_{4}\right)_{3-\mathrm{x}}(\mathrm{OH})_{4 \mathrm{x}}(\mathrm{x}>1.5)\right)$; these are major contributors to its high alkalinity $(\mathrm{pH}=10.54)$ (Liao et al., 2015). Following the addition of gypsum, andradite, katoite, and cancrinite all decreased as evaluated by the narrow and intense peaks in the XRD spectra (Fig. 1), which may indicate that $\mathrm{pH}$ of the residues decreased.

The EC value was $2.39 \mathrm{mS} / \mathrm{cm}$ in BG1 and increased with increasing gypsum rate which may well be due to the formation of soluble salts with the addition of gypsum. Courtney et al. (2009) found that application of gypsum significantly increased the EC value $(0.37$ to $2.43 \mathrm{mS} / \mathrm{cm})$. Addition of gypsum increased the content of exchangeable $\mathrm{Ca}^{2+}$ which ranged from $45.12 \%$ to $48.57 \%$ in $\mathrm{BG} 1$ and significantly increased with increasing gypsum addition. Significant changes also occurred in BG1 and BG2 for exchangeable $\mathrm{Na}^{+}$and ESP, whilst a slight variation for exchangeable $\mathrm{K}^{+}$and $\mathrm{Mg}^{2+}$ occurred. Compared to BG1, addition of vermicompost (BF1 or BF2) revealed a low EC but a high ESP. This indicated that vermicompost may reduce salinity which is consistant with results from Oo et al. (2013). A similar trend was reported by Wong \& Ho (1994) following application of sewage sludge and Jones et al. (2011) following addition of poultry manure; the effect being attributed to organic amendments having a greater absorption capacity for sodium.

Addition of vermicompost significantly reduced bulk density and increased total porosity of bauxite residue and at higher rates the change was more obvious (Table 1). Changes in bulk density and porosity in the amended residues were of importance as they may improve physical conditions including increased water holding capacity, aeration, and assist root penetration which may benefit plant establishment (Majou et al., 2008). Courtney and Mullen (2008) reported that organic compost application to soil would also reduce bulk density. Aksakal et al. (2016) observed that the lowest mean bulk density and the highest mean total porosity occurred when the most vermicompost was added. Total organic carbon content increased with compost addition rates; TOC content ranged from 3.54 to $7.17 \mathrm{~g} / \mathrm{kg}$ in BF1 which may have an effect on bulk density of the treated residues (Tejada \& Gonzalez, 2008). Furthermore, addition of compost significantly increased exchangeable $\mathrm{Mg}^{2+}$ and $\mathrm{K}^{+}$. Jones et al. (2012) investigated the effects of organic amendments on the properties of gypsum-treated residue, and also found that addition of compost increased exchangeable $\mathrm{Mg}^{2+}$ and $\mathrm{K}^{+}$.

Unamended residue had a high pH, ESP, and bulk density with a poor structural substrate (Gräfe \& Klauber, 2011), whilst organic carbon had been reported as less than 0.3\% (Courtney et al., 2014). The combined addition of gypsum and vermicompost increased the proportion of sand-size particles and changed the texture of the residues. Furthermore, the combination changed bulk density, porosity and organic carbon, whilst reducing pH, EC and ESP in the residues. Wong and Ho (1993) found that addition of gypsum reduced $\mathrm{pH}, \mathrm{EC}$, and provided an excess supply of $\mathrm{Ca}^{2+}$ which may lead to a low ESP. Courtney et al. (2013) found that gypsum and compost may ameliorate physical and chemical properties of bauxite residue to benefit plant establishment on disposal areas. Compared to addition with gypsum or vermicompost alone, their combination had a significant improvement on physicochemical properties of the residues. 
Residue aggregate size distribution results from the modified Le Bissonnais' method are presented in Fig. 2. For the FW test, the $<0.25 \mathrm{~mm}$ residue aggregates were the major fraction. In the unamended residues (B), the proportion of 2-1 mm and 1-0.25 mm aggregates were $1.04 \%$ and $7.89 \%$, respectively. With addition of gypsum (BG1), the proportion of 2-1 mm aggregates increased from $1.04 \%$ and $3.27 \%$, whilst the proportion of $1-0.25 \mathrm{~mm}$ aggregates decreased slightly from $7.89 \%$ to $7.54 \%$. Addition of vermicompost increased the proportion of 2-1 mm aggregates (1.04\% to $4.31 \%)$ and $1-0.25$ $\mathrm{mm}$ aggregates (7.89\% to $8.63 \%)$. Compared to gypsum addition, the residue had a higher proportion of water-stable aggregates $(0.25-2 \mathrm{~mm})$ following addition of vermicompost, which indicated that vermicompost may have a more positive effect on water-stable macroaggregate formation.

The combination of gypsum and vermicompost had a significant effect on aggregate size distribution. The proportion of 2-1 mm and 1-0.25 mm aggregates in BG1F1 increased to 5.95\% and $12.46 \%$, respetively. The fraction of water-stable aggregates $(>0.25 \mathrm{~mm})$ accounted for approximately $18.41 \%$, which indicated that their combined addition was more benefitial to macroaggregate stability of the residue. For the SW test, $<0.05 \mathrm{~mm}$ aggregates were the major fraction in unamended residues (B). Addition of gypsum increased the proportion of $>0.25 \mathrm{~mm}$ aggregates. Compared to gypsum, addition of vermicompost had a postive effect on the $2-1 \mathrm{~mm}$ and 2-0.25 mm aggregate fractions. With the addition of gypsum and vermicompost, the major fraction was the 2-1 mm aggregates. For the WS test, the combination of gypsum and vermicompost increased the 2-1 $\mathrm{mm}$ aggregate fraction. In residues $\mathrm{BG} 2 \mathrm{~F} 1$ and $\mathrm{BG} 2 \mathrm{~F} 2$, the major fraction was the 2-1 mm aggregates. Compared to the FW and WS tests, aggregate size was larger following the SW test, indicating that differential clay swelling was the least distructive mechamism occuring in the residues.

The modified Le Bissonnais' method showed significant differences in MWD of the residues (Fig. 3). Following the three tests (FW, SW and WS), the value of MWD in unamended residue (B) was 0.15 $\mathrm{mm}, 0.35 \mathrm{~mm}$ and $0.19 \mathrm{~mm}$, respectively. This indicated that the three tests had remarkable differences on aggregate stability of bauxite residue. The FW test and the WS test had significant effects on particle disaggregation. Unamended residue revealed the least aggregate stability, which indicated that it had poor aggregate structure preventing vegetation growth. For the FW test, variation on MWD of the residues under nine treatments was not obvious. Maximum MWD was approximately $0.23 \mathrm{~mm}$ and the mininum MWD was $0.10 \mathrm{~mm}$. For the SW and WS tests, MWD increased significantly. The residues had a higher MWD with addition of compost than gypsum alone, which indicated that addition of compost had a better effect on aggregate stability of the residues. The combination of compost and gypsum increased the MWD effectively improving aggregate stability.

Aggregate stability is an important factor in assessing soil physical quality and maintaining long-term crop productivity (Gelaw et al., 2015; San José Martínez et al., 2015). Improved soil aggregate stability may benefit root penetration, water transportion, gas diffusion and seedling emergence (Hartley et al., 2016). Mizuta et al. (2015) observed that addition of starch or cellulose to soil increased fractions of macro-aggregates $(>1 \mathrm{~mm})$ significantly and aggregate stability of the soil improved. Aksakal et al. (2016) found that vermicompost applications increased the fraction of water-stable aggregates and improved wet aggregate stability of agriculture soil. Asensio et al. (2013) found that waste organic amendments improved the proportion of water-stable aggregates and enhanced the structural stability of copper mine soils. Courtney et al. (2013) discovered that addition of gypsum may also improve macroaggregate stability of the residues, as gypsum could effectively reduce $\mathrm{pH}$ and ESP. 
The erodibility factor (K) is usually used to assess soil erosion resistance (Wang et al., 2013). A high value of $\mathrm{K}$ indicates a less stable physical structure. Significant differences in $\mathrm{K}$ of the residues is presented in Fig. 2. Unamended residues had high values of $\mathrm{K}(0.27,0.23$ and 0.29$)$ following the three tests which demonstrated that unamended residue had a less stable structure to resist water erosion. From the three tests, residues had the highest $\mathrm{K}$ value following the FW test and lowest $\mathrm{K}$ value following the SW test. This indicates that residues are most susceptible to erosion with the FW test and least sensitive with the SW test. For the SW and WS tests, the K value decreased with the nine treatments indicating that addition of compost and gypsum significantly improved the resistance of bauxite residue to water erosion.

The three tests from the modified Le Bissonnais' method exhibited different characteristics to the main breakdown machanisms (Le Bissonnais, 1996). Slaking was the major breakdown mechanisms in the FW test which involved internal pressure by air entrapment during rewetting. Slaking disaggregated microaggregates according to porosity, wettability and internal cohesion of soil properties. Differential swelling was the major breakdown mechanism in the SW test which involved internal pressure by clay differential swelling. The SW test had limited power to disaggregate macroand micro-aggregates according to swelling potential, wetting conditions and cohesion of soils. Mechanical breakdown was the major mechanism in the WS test which involved external pressure by raindrop impact. The WS test had cumulative intensity to disaggregate elementary particles according to clay, organic carbon and oxides contents of soils (Amézketa, 1999). The K value following the FW test was greater than the SW and WS tests, which may indicate that rainstorm events or extreme flooding could disaggregate and destroy the physical structure of bauxite residue. Under conditions of light rain or drip irrigation (SW or WS test), addition of amendments had a more significant effect on improving aggregate stability and erosion resistance than unamended residues. Santini \& Fey (2013) found that artificial irrigation and drainage were essential to remove excess $\mathrm{Na}^{+}$and support plant growth on disposal areas, irrigation is required to ensure plant and microorganism growth. As adequate flushing of excess $\mathrm{Na}$ in bauxite residue was a prerequisite to lower $\mathrm{Na}^{+}$content and support vegetation establishment, several irrigation types, including furrow irrigation or hand watering, may be necessary under the processes of substrate amendment. For unamended residues, three different tests had significant breakdown effects on residue aggregates, which indicated that regular irrigation types could be used to remove excess Na. Courtney et al. (2013) found that restoration management on bauxite residue should aim to reduce ESP prior to promoting aggregation. When residue Na content decreased, drip irrigation would be the most appropriate method to improve substrate amelioration and vegetation establishment. Chauhan \& Gangyly (2011) observed that drip irrigation was most effective in improving plant growth on ameliorated residues, which was in accordance with this study.

\section{Residue microaggregate formation}

The $<20 \mu \mathrm{m}$ residue aggregates were the main proportion, which accounted for more than $68 \%$ of the total weight in unamended residue (B) (Table 2). Microaggregate fractions in unamended residue increased in the following order: $10-5 \mu \mathrm{m}>20-10 \mu \mathrm{m}>5-2 \mu \mathrm{m}>50-20 \mu \mathrm{m}>250-50 \mu \mathrm{m}$. The $<2 \mu \mathrm{m}$ aggregates were the smallest proportion, accounting for only $1.2 \%$. Addition of gypsum increased the proportion of $250-50 \mu \mathrm{m}$ and 10-5 $\mu \mathrm{m}$ aggregates. In BG2, the proportion of $250-50 \mu \mathrm{m}$ aggregates increased from $11.2 \%$ to $11.5 \%$, whilst the proportion of $10-5 \mu \mathrm{m}$ aggregates increased from $24.6 \%$ to $25.2 \%$. Addition of vermicompost significantly increased the proportion of 250-50 $\mu \mathrm{m}$ aggregates. In BF2, the proportion of $250-50 \mu \mathrm{m}$ aggregates increased to $14.2 \%$, which was 
greater than that from addition of gypsum. This indicated that organic carbon was more efficient for the formation of large microaggregates. Compared to the addition of vermicompost, the combination of vermicompost and gypsum had a slight effect on the increased proportion of 50-10 $\mu \mathrm{m}$ aggregates, which indicated that gypsum may have more effect on the aggregation of 50-10 $\mu \mathrm{m}$ particles.

Mean weight diameter (MWDm) and aggregated silt+clay (ASC) were selected as indicators to evaluate residue microaggregate stability following the treatments. High values of MWDm and ASC indicated MWDm of the residues ranged from 2.95 to $3.41 \mathrm{~mm}$, whilst the value of ASC ranged from $17 \%$ to $24 \%$ (Fig. 4). This showed that gypsum and/or vermicompost addition may enhance microaggregate stability of bauxite residue. As can be seen, gypsum had a positive effect on the value of ASC and vermicompost improved the value of $\mathrm{MWD}_{\mathrm{m}}$. A high proportion of aggregates with large size indicated a high value of MWD, whilst a high ASC value meant a high proportion of silt- and clay-size aggregates (Campo et al., 2014). Vermicompost may significantly increase the proportion of larger microaggregates, whilst gypsum may cause the main flocculating mehcanism on the proportion of silt- and clay-size particles. Piccolo \& Mbagwu (1990) found that organic waste addition in soils induced aggregation effects on sand-size aggregates and soil microaggregate stability was significantly correlated with humic substances content. Smith et al. (2015) observed that microaggregate stability was attributed to the dominance of $\mathrm{Ca}^{2+}$ over $\mathrm{Na}^{+}$on clay-exchange sites and organic matter may play a role in microaggregate stabilisation through its capacity to lower soil $\mathrm{pH}$ and increase the availability of $\mathrm{Ca}^{2+}$.

\section{Residue micromorphology}

As gypsum and vermicompost had positive effects on residue aggregation, residue specimens of B, BG1 and BG1F2 were selected to investigate the changes of aggregate structure and elemental distribution on aggregate surfaces by SEM-EDS. The micromorphology of residue macroaggregates $(2-1 \mathrm{~mm})$ is shown in Fig. 5 and the micromorphology of residue microaggregates $(<0.05 \mathrm{~mm})$ is shown in Fig. 6. SEM imaging of untreated residue macroaggregate (Fig. 5) revealed that the particles of 0.5-1 $\mu \mathrm{m}$ were the major fraction. Residue macroaggregates (B) had a sheet-like structure with many fine fragments. With the addition of gypsum, the quantity of macroaggregates (BG1) with a sheet-like structure increased significantly (Fig. 5). The size of the sheet-like structure became larger and the major fraction were the $2-5 \mu \mathrm{m}$ particles. The combination of vermicompost and gypsum changed the residues to a more dense structure (Fig. 5). There were a large amount of fine particles with granular structures attached to macroaggregate surfaces. As shown in Fig. 6, addition of vermicompost and gypsum improved aggregate structure from a sheet-like assembly to a prismatic arrangement, whilst the 1-3 $\mu \mathrm{m}$ fraction of microaggregates significantly decreased. Kong et al. (2017b) investigated the effects of amendments on residue micromorphology and found that gypsum addition accelerated the fraction of $0.2-1 \mu \mathrm{m}$ in 2-5 $\mu \mathrm{m}$ aggregates due to calcium's positive effect on particle flocculation.

According to energy-dispersive $\mathrm{x}$-ray analysis on the surface of residue aggregates, this revealed that $\mathrm{Na}, \mathrm{Al}, \mathrm{Si}, \mathrm{Ca}$ and $\mathrm{Fe}$ were the major chemical elements in residue aggregates. The contents of $\mathrm{Na}$, $\mathrm{Al}, \mathrm{Ca}$ and $\mathrm{Fe}$ in untreated residue macroaggregate accounted for $7.08 \%, 15.16 \%, 15.51 \%$ and $10.69 \%$, respectively (Fig. 5). Addition of gypsum significantly increased the content of $\mathrm{Ca}$, whilst reducing the $\mathrm{Na}$ content. BG1F2 showed a further reduction in the content of $\mathrm{Na}(3.06 \%)$ which was possibly due to the change in physical structure of the treated residue. Addition of gypsum and vermicompost 
improved the physical condition of bauxite residue, which may be benefitial to the leaching of soluble $\mathrm{Na}$ and decreasing $\mathrm{Na}^{+}$on aggregate surfaces.

Compared to elemental distribution of residue macroaggregates, microaggregates of untreated residues had lower Ca contents (Fig. 6). For treated residue microaggregates, $\mathrm{Ca}$ content on aggregate surfaces increased. Addition of $2 \%$ gypsum improved Ca content from $5.52 \%$ to $24.39 \%$, which was greater than in residue macroaggregates. Zhu et al. (2016b) found that following natural stacking processes, $\mathrm{Ca}$ content on microaggregate surfaces (3.34\% to $16.74 \%)$ was greater than on macroaggregate surfaces ( $7.62 \%$ to $20.69 \%$ ).

Many field trials have been established to ameliorate the physical and chemical properties of bauxite residue in order to establish a plant cover (Jones \& Haynes, 2011). Gypsum (phosphogypsum) and organic waste have been regarded as effective amendments to improve revegetation (Courtney et al., 2009; Jones et al., 2012). The addition of gypsum and vermicompost improved residue aggregate structure which may be benefitial to the growth of plant roots and to improve the capacity of water and nutrients. Nevertheless, the global inventory of 4 billion tons of bauxite residue therefore requires large volumes of ameliorants to accelerate the restoration process at disposal areas. The selection of amendments on the disposal area should be based on travel distance, mass/weight, associated risks and unknown side effects. Organic waste improved the physical structure and organic carbon content of the residues. Results obtained in this study indicated that gypsum and vermicompost application was an effective way to improve chemical properties and physical structure of bauxite residue. Vermicompost may be an appropriate organic amendment for substrate amelioration in bauxite residue disposal areas. Other organic wastes such as straw (paddy or wheat), bagasse, or biosolids could also be applied to the residues and may therefore be considered as a promising way forward.

\section{CONCLUSIONS}

High alkalinity, low organic carbon content and poor aggregate stability are common characteristics of newly stacked bauxite residue. This work investigated the effects of gypsum and vermicompost on aggregate formation of bauxite residue using pot experiments. Addition of gypsum significantly reduced $\mathrm{pH}$ and increased $\mathrm{EC}$, whilst addition of vermicompost had a positive effect on bulk density, porosity and organic carbon content. The selected amendments improved aggregate stability and microaggregate stability of the residue. Both gypsum and vermicompost may well improve the proportion of water-stable aggregates and mean weight diameter (MWD), nevertheless, the improvement effect from vermicompost addition was exceptional. Vermicompost significantly increased the fraction of 250-50 $\mu \mathrm{m}$ microaggregates, and gypsum stimulated the flocculation of $<20$ $\mu \mathrm{m}$ particles. Residue micromorphology revealed that the combination of gypsum and vermicompost improved aggregate structure whilst changing the distribution of chemical elements on aggregate surfaces. The present study suggests that addition of gypsum and vermicompost may stimulate aggregate formation, improve aggregate stability and ameliorate aggregate structure of bauxite residue. Future research should focus on screening novel amendments, whilst assessing the regulation of aggregate formation on disposal areas at the field scale.

\section{ACKNOWLEDGEMENT}

Financial support from Environmental protection's special scientific research for Chinese public 
welfare industry (No. 201509048) and National Natural Science Foundation of China (No. 41371475) are gratefully acknowledged.

\section{REFERENCES}

Aksakal EL, Sari S, Angin I. 2016. Effects of vermicompost application on soil aggregation and certain physical properties. Land Degradation \& Development 27: 983-995. DOI: 10.1002/ldr.2350.

Amézketa E. 1999. Soil aggregate stability: a review. Journal of Sustainable Agriculture 14: 83-151. DOI: 10.1300/J064v14n02_08.

An S, Darboux F, Cheng M. 2013. Revegetation as an efficient means of increasing soil aggregate stability on the Loess Plateau (China). Geoderma 209-210: 75-85. DOI:10.1016/j.geoderma.2013.05.020.

Asensio V, Vega FA, Andrade ML, Covelo EF. 2013. Tree vegetation and waste amendments to improve the physical condition of copper mine soils. Chemosphere 90: 603-610. DOI: 10.1016/j.chemosphere.2012.08.050.

Banning NC, Sawada Y, Phillips IR, Murphy DV. 2014. Amendment of bauxite residue sand can alleviate constraints to plant establishment and nutrient cycling capacity in a water-limited environment. Ecological Engineering 62: 179-187. DOI: 10.1016/j.ecoleng.2013.10.034.

Biederman LA, Boutton TW, Whisenant SG. 2008. Nematode community development early in ecological restoration: the role of organic amendments. Soil Biology \& Biochemistry 40: 2366-2374. DOI: 10.1016/j.soilbio.2008.05.017.

Campo J, Gimeno-García E, Andreu V, González-Pelayo O, Rubio JL. 2014. Cementing agents involved in the macro- and microaggregation of a Mediterranean shrubland soil under laboratory heating. Catena 113: 165-176. DOI: 10.1016/j.catena.2013.10.002.

Chauhan S, Ganguly A. 2011. Standardizing rehabilitation protocol using vegetation cover for bauxite waste (red mud) in eastern India. Ecological Engineering 37: 504-510. DOI: 10.1016/j.ecoleng.2010.12.017.

Courtney RG, Mullen GJ. 2008. Soil quality and barley growth as influenced by the land application of two compost types. Bioresource Technology 99: 2913-2918. DOI: 10.1016/j.biortech.2007.06.034.

Courtney RG, Jordan SN, Harrington T. 2009. Physico-chemical changes in bauxite residue following application of spent mushroom compost and gypsum. Land Degradation \& Development 20: 572-581. DOI: 10.1002/ldr.926.

Courtney R, Kirwan L. 2012. Gypsum amendment of alkaline bauxite residue-plant available aluminium and implications for grassland restoration. Ecological Engineering 42: 279-282. DOI: 10.1016/j.ecoleng.2012.02.025.

Courtney R, Feeney EO, Grady A. 2014. An ecological assessment of rehabilitated bauxite residue. Ecological Engineering 73: 373-379. DOI: 10.1016/j.ecoleng.2014.09.064.

Courtney R., Harrington T, Byrne KA. 2013. Indicators of soil formation in restored bauxite residues. Ecological Engineering 58: 63-68. DOI: 10.1016/j.ecoleng.2013.06.022.

Danielson RE, Sutherland PL. 1986. Porosity. In: Methods of Soil Analysis. Part 1: Physical Properties, Klute A (ed.). American Society of Agronomy: Madison, Wisconsin; 443-460.

Deviren Saygın S, Cornelis WM, Erpul G, Gabriels D. 2012. Comparison of different aggregate stability approaches for loamy sand soils. Applied Soil Ecology 54: 1-6. DOI: 10.1016/j.apsoil.2011.11.012.

Falsone G, Celi L, Stanchi S, Bonifacio E. 2016. Relative importance of mineralogy and organic matter characteristics on macroaggregate and colloid dynamics in mg-silicate dominated soils. Land Degradation \& Development. DOI: $10.1002 / 1 \mathrm{dr} .2516$.

Fornes F, Mendoza-Hernández D, García-De-La-Fuente R, Abad M, Belda RM. 2012. Composting versus vermicomposting: a comparative study of organic matter evolution through straight and combined processes. Bioresource Technology 118: 296-305. DOI: 10.1016/j.biortech.2012.05.028. 
Gelaw AM, Singh BR, Lal R. 2015. Organic carbon and nitrogen associated with soil aggregates and particle sizes under different land uses in Tigray, Northern Ethiopia. Land Degradation \& Development 26: 690-700. DOI: 10.1002/ldr.2261.

Goloran JB, Phillips IR, Chen CR. 2016. Forms of nitrogen alter plant phosphorus uptake and pathways in rehabilitated highly alkaline bauxite processing residue sand. Land Degradation \& Development. DOI: 10.1002/ldr.2630.

Gräfe M, Klauber C. 2011. Bauxite residue issues: IV. old obstacles and new pathways for in situ residue bioremediation. Hydrometallurgy 108: 46-59. DOI: 10.1016/j.hydromet.2011.02.005.

Hartley W, Riby P, Waterson J. 2016. Effects of three different biochars on aggregate stability, organic carbon mobility and micronutrient bioavailability. Journal of Environmental Management 181: 770-778. DOI: 10.1016/j.jenvman.2016.07.023.

Jones BEH, Haynes RJ. 2011. Bauxite processing residue: a critical review of its formation, properties, storage, and revegetation. Critical Reviews in Environmental Science and Technology 41: 271-315. DOI: 10.1080/10643380902800000.

Jones BEH, Haynes RJ, Phillips IR. 2011. Influence of organic waste and residue mud additions on chemical, physical and microbial properties of bauxite residue sand. Environmental Science and Pollution Research 18: 199-211. DOI: $10.1007 / \mathrm{s} 11356-010-0364-5$.

Jones BEH, Haynes RJ, Phillips IR. 2012. Addition of an organic amendment and/or residue mud to bauxite residue sand in order to improve its properties as a growth medium. Journal of Environmental Management 95: 29-38. DOI: 10.1016/j.jenvman.2011.09.014.

Kaur N, Phillips I, Fey MV. 2016. Amelioration of bauxite residue sand by intermittent additions of nitrogen fertiliser and leaching fractions: The effect on growth of kikuyu grass and fate of applied nutrients. Science of the Total Environment 550: 362-371. DOI: 10.1016/j.scitotenv.2016.01.012.

Klauber C, Gräfe M, Power G. 2011. Bauxite residue issues: II. options for residue utilization. Hydrometallurgy 108: 11-32. DOI: 10.1016/j.hydromet.2011.02.007.

Kong XF, Guo Y, Xue SG, William H, Wu C, Ye YZ, Cheng QY. 2017a. Natural evolution of alkaline characteristics in bauxite residue. Journal of Cleaner Production 143: 224-230. DOI: 10.1016/j.jclepro.2016.12.125.

Kong XF, Li M, Xue SG, Hartley W, Chen CR, Wu C, Li XF, Li YW. 2017b. Acid transformation of bauxite residue: conversion of its alkaline characteristics. Journal of Hazardous Materials 324: 382-390. DOI: 10.1016/j.jhazmat.2016.10.073.

Le Bissonnais Y. 1996. Aggregate stability and assessment of soil crustability and erodibility. 1. Theory and methodology. European Journal of Soil Science 47: 425-437. DOI: 10.1111/j.1365-2389.1996.tb01843.x.

Li LY. 1998. Properties of red mud tailings produced under varying process conditions. Journal of Environmental Engineering 124: 254-264. DOI: 10.1061/(ASCE)0733-9372(1998)124:3(254).

Liao CZ, Zeng L, Shih, K. 2015. Quantitative X-ray diffraction (QXRD) analysis for revealing thermal transformations of red mud. Chemosphere 131: 171-177. DOI: 10.1016/j.chemosphere.2015.03.034.

Liu W, Chen X, Li W, Yu Y, Yan K. 2014. Environmental assessment management and utilization of red mud in China. Journal of Cleaner Production 84: 606-610. DOI: 10.1016/j.jclepro.2014.06.080.

Liu W, Yang J, Xiao B. 2009. Review on treatment and utilization of bauxite residues in China. International Journal of Mineral Processing 93: 220-231. DOI: 10.1016/j.minpro.2009.08.005.

Manrique LA, Jones CA. 1991. Bulk density of soils in relation to soil physical and chemical properties. Soil Science Society of America Journal 2: 476-481. DOI: 10.2136/sssaj1991.03615995005500020030x.

Majou HA, Bru A, Duval O, Bas CL, Vautier A. 2008. Prediction of soil water retention properties after stratification by combining texture, bulk density and type of horizon. Soil Use \& Management 24: 383-391. DOI: 10.1111/j.1475-2743.2008.00180.x.

Mbagwu JSC, Auerswald K. 1999. Relationship of percolation stability of soil aggregates to land use, selected properties, structural indices and simulated rainfall erosion. Soil \& Tillage Research 50: 197-206. DOI: 10.1016/S0167-1987(99)00006-9.

Mizuta K, Taguchi S, Sato S. 2015. Soil aggregate formation and stability induced by starch and cellulose. Soil Biology and 
Biochemistry 87: 90-96. DOI: 10.1016/j.soilbio.2015.04.011.

Monreal CM, Schnitzer M, Schulten HR., Campbell CA, Anderson DW. 1995. Soil organic structures in macro and microaggregates of a cultivated Brown Chernozem. Soil Biology and Biochemistry 27: 845-853. DOI: 10.1016/0038-0717(94)00220-U.

Newson T, Dyer T, Adam C, Sharp S. 2006. Effect of structure on the geotechnical properties of bauxite residue. Journal of Geotechnical and Geoenvironmental Engineering 132: 143-151. DOI: 10.1061/(ASCE)1090-0241(2006)132:2(143).

Oo AN, Iwai CB, Saenjan P. 2013. Soil properties and maize growth in saline and nonsaline soils using cassava-industrial waste compost and vermicompost with or without earthworms. Land Degradation \& Development 26: 300-310. DOI: 10.1002/ldr.2208.

Pan X, Yu H, Tu G. 2015. Reduction of alkalinity in bauxite residue during Bayer digestion in high-ferrite diasporic bauxite. Hydrometallurgy 151: 98-106. DOI: 10.1016/j.hydromet.2014.11.015.

Piccolo A, Mbagwu JSC. 1990. Effects of different organic waste amendments on soil microaggregates stability and molecular sizes of humic substances. Plant and Soil 123: 27-37. DOI: 10.1007/BF00009923.

Saha D, Kukal SS. 2015. Soil structural stability and water retention characteristics under different land uses of degraded lower himalayas of north-west India. Land Degradation \& Development 26:263-271. DOI: 10.1002/ldr.2204.

San José Martínez F, Muñoz Ortega FJ, Caniego Monreal FJ, Kravchenko AN, Wang W. 2015. Soil aggregate geometry: measurements and morphology. Geoderma 237-238: 36-48. DOI: 10.1016/j.geoderma.2014.08.003.

Santini TC, Fey MV. 2013. Spontaneous vegetation encroachment upon bauxite residue (red mud) as an indicator and facilitator of in situ remediation processes. Environmental Science \& Technology 47: 12089-12096. DOI: 10.1021/es402924g.

Santini TC, Kerr JL, Warren LA. 2015. Microbially-driven strategies for bioremediation of bauxite residue. Journal of Hazardous Materials 293: 131-157. DOI: 10.1016/j.jhazmat.2015.03.024.

Sinha RK, Agarwal S, Chauhan K, Valani D. 2010. The wonders of earthworms \& its vermicompost in farm production: Charles Darwin's 'friends of farmers', with potential to replace destructive chemical fertilizers. Agricultural Sciences 1: 76-94. DOI: 10.4236/as.2010.12011.

Smart D, Callery S, Courtney R. 2016. The potential for waste-derived materials to form soil covers for the restoration of mine tailings in Ireland. Land Degradation \& Development 27: 542-549. DOI: 10.1002/ldr.2465.

Smith R, Tongway D, Tighe M, Reid N. 2015. When does organic carbon induce aggregate stability in vertosols? Agriculture, Ecosystems \& Environment 201: 92-100. DOI: 10.1016/j.agee.2014.12.002.

Sochan A, Bieganowski A, Ryżak M, Dobrowolski, R, Bartmiński P. 2012. Comparison of soil texture determined by two dispersion units of Mastersizer 2000. International Agrophysics 26: 99-102. DOI: 10.2478/v10247-012-0015-9.

Tejada M, Gonzalez JL. 2008. Influence of two organic amendments on the soil physical properties, soil losses, sediments and runoff water quality. Geoderma 145: 325-334. DOI: 10.1016/j.geoderma.2008.03.020.

Verdenelli RA, Lamarque AL, Meriles JM. 2012. Short-term effects of combined iprodione and vermicompost applications on soil microbial community structure. Science of the Total Environment 414: 210-219. DOI: 10.1016/j.scitotenv.2011.10.066.

Wang B, Zheng F, Römkens MJM, Darboux F. 2013. Soil erodibility for water erosion: a perspective and Chinese experiences. Geomorphology 187: 1-10. DOI: 10.1016/j.geomorph.2013.01.018.

Wehr JB, Fulton I, Menzies NW. 2006. Revegetation strategies for bauxite refinery residue: a case study of alcan gove in Northern Territory, Australia. Environmental Management 37: 297-306. DOI: 10.1007/s00267-004-0385-2.

Wong JWC, Ho GE. 1993. Use of waste gypsum in the revegetation on red mud deposits: a greenhouse study. Waste Management \& Research 11: 249-256. DOI: 10.1177/0734242X9301100306.

Wong JWC, Ho GE. 1994. Sewage sludge as organic ameliorant for revegetation of fine bauxite refining residue. Resources Conservation \& Recycling 11: 297-309. DOI: 10.1016/0921-3449(94)90097-3.

Xue SG, Zhu F, Kong XF, Wu C, Huang L, Huang N, Hartley W. 2016. A review of the characterization and revegetation of bauxite residues (red mud). Environmental Science and Pollution Research 23: 1120-1132. DOI: 
Yilmaz E. 2014. Assessment of the role of agricultural wastes in aggregate formation and their stability. Journal of Environmental Management 144: 93-100. DOI: 10.1016/j.jenvman.2014.05.023.

Zhu F, Li XF., Xue SG, Hartley W, Wu C, Han FS. 2016a. Natural plant colonization improves the physical condition of bauxite residue over time. Environmental Science and Pollution Research 23: 22897-22905. DOI: 10.1007/s11356-016-7508-1.

Zhu F, Liao JX, Xue SG, Hartley W, Zou Q, Wu H. 2016b. Evaluation of aggregate microstructures following natural regeneration in bauxite residue as characterized by synchrotron-based X-ray micro-computed tomography. Science of The Total Environment 573: 155-163. DOI: 10.1016/j.scitotenv.2016.08.108.

Zhu F, Xue SG, Hartley W, Huang L, Wu C, Li XF. 2016c. Novel predictors of soil genesis following natural weathering processes of bauxite residues. Environmental Science and Pollution Research 23: 2856-2863. DOI: $10.1007 / \mathrm{s} 11356-015-5537-9$

Zhu F, Zhou JY, Xue SG, Hartley W, Wu C, Guo Y. 2016d. Aging of bauxite residue in association of regeneration: a comparison of methods to determine aggregate stability \& erosion resistance. Ecological Engineering 92: 47-54. DOI: 10.1016/j.ecoleng.2016.03.025. 